\title{
EDITORIAL
}

\section{PROGRAMA DE VOLTA PARA CASA 15 ANOS DE LIBERDADE}

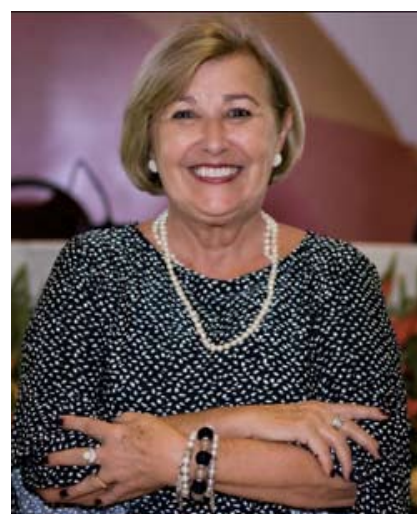

Dorisdaia Carvalho de Humerez Coordenadora da Câmara Técnica de Educação e Pesquisa, CTEP. Conselho Federal de Enfermagem

A hegemonia das estratégias manicomiais foi sempre questionada em seus aspectos éticos, jurídicos, econômicos, políticos e sociais e a transformação da institucionalização das pessoas com transtornos mentais se tornou realidade com a Reforma psiquiátrica.

A Política de Saúde Mental no Brasil promove a redução programada de leitos psiquiátricos de longa permanência, incentivando que as internações, quando necessárias, se deem no âmbito dos hospitais gerais e que sejam de curta duração.

A Reforma Psiquiátrica, Lei 10.216/2001, bem como o amplo conjunto normativo, impõe ao Estado brasileiro o compromisso com uma política de saúde mental firmada sobre princípios da inclusão e liberdade.

Visa à constituição de uma rede de dispositivos diferenciados que permitam a atenção ao portador de sofrimento mental em seu território, no lugar onde vive e, ações que permitam a reabilitação psicossocial por meio da inserção pelo trabalho, cultura e lazer, bem como estimular o exercício pleno de seus direitos civis, políticos e de cidadania.

Dentre as estratégias de atenção a saúde mental o "Programa De Volta Para Casa", criado pelo Ministério da
Saúde, estabelecido pela Lei Federal 10.708/2003, que dispõe sobre a regulamentação do auxílio-reabilitação psicossocial para assistência, acompanhamento e integração social, fora da unidade hospitalar, das pessoas acometidas de transtornos mentais, com história de longa internação psiquiátrica.

O Programa, que agora completa 15 anos e representa um dos instrumentos mais efetivos, estratégia potencializadora de emancipação para a reintegração social de pessoas com longo histórico de hospitalização.

Eram vidas fortemente marcadas por longo processo de exclusão e desumanização, mas que expressam imensa capacidade de resiliência e reconstrução. Foram destituídos da sua identidade, privados de seus direitos básicos, de liberdade, sem possibilidade de voz ou de possuir qualquer coisa de seu, mas os que sobreviveram, vivem. Há 15 anos temos novos personagens nas cidades, vizinhos, trabalhadores, estudantes e artistas. Compuseram e compõem novas histórias no mundo.

O manicômio como modelo de atenção psiquiátrica, mesmo sem forças frente à reforma psiquiátrica, ainda se mantém vivo em práticas manicomiais enraizadas, como a naturalização da violência institucional e implica, portanto, em atitude de denúncia, de não comunhão com posturas estigmatizantes e radicais, visando diminuir as arbitrariedades cometidas no cotidiano das instituições que albergam a cultura manicomial e o desejo do manicômio mental, o que garante que a luta antimanicomial não pode parar.

Nesse número os leitores lerão temas variados, mas teríamos que lembrar aos profissionais dos 15 anos de liberdade, que com auxílio de políticas públicas no Sistema Único de Saúde, pôde tornar realidade o direito das pessoas com transtorno mental de existir e viver com cidadania. 